\title{
Expression of Concern: The functional role of long non-coding RNAs and epigenetics
}

Shulin Li

\section{Expression of Concern}

After publication of this article [1] it was brought to the Editors' attention that the same manuscript had been submitted to another journal by a different author while this article was still under consideration. We have been unable to confirm the authorship despite contacting the authors' institutions and requesting an investigation.

Received: 25 April 2016 Accepted: 25 April 2016

Published online: 09 June 2016

\section{References}

1. Cao J. The functional role of long non-coding RNAs and epigenetics. Biological Procedures Online. 2014;16:11. doi:10.1186/1480-9222-16-11.

Correspondence: sli4@mdanderson.org

This comment refers to the article available at: http://dx.doi.org/10.1186/ 1480-9222-16-11.

Department of Pediatrics-Research, Unit 0853, The University of Texas MD Anderson Cancer Center, Houston, USA

\footnotetext{
Submit your next manuscript to BioMed Central and we will help you at every step:

- We accept pre-submission inquiries

- Our selector tool helps you to find the most relevant journal

- We provide round the clock customer support

- Convenient online submission

- Thorough peer review

- Inclusion in PubMed and all major indexing services

- Maximum visibility for your research
}

Submit your manuscript at www.biomedcentral.com/submit 